\title{
Myth and Trivia: The double encoding of the Irish representations in the novel At Swim-Two-Birds
}

\author{
Safta Cristina Elena
}

I set out from the working hypothesis that Flann O'Brien's novel, At Swim-Two-Birds is a satire on contemporary and mythological Ireland. The author seems to have created an epic representation of the Irish myth and inception using the mask of trivia, of encoded messages placed in the storyline of a seemingly ridiculed society. This story within a story uses a literary device, comparable to that of presentational theatre, where the actor does not allow the audience to forget they are watching a play, as O'Brien himself mentions: "a self-evident sham, to which the reader could regulate at will the degree of his credulity" (O'Brien, p. 25). Within this noticeably ironic and contradictory lecture, the tumultuous loss of Irish spirituality is evidenced. The heroic characters praised by Ireland's legends are included in a contemporary reality show fusing with the after-war decayed society.

This paper aims to cast light upon O'Brien's codification from within his work, At Swim-Two-Birds, which unveils the lost spiritual heroic Ireland, through a mix of mythical allusions and banal incidents calling forth his famous ironic statement regarding Associate Professor Schrödinger's work for the Trinity College of Dublin and his efforts to prove "that you cannot establish a first cause". O'Brien ironized this as being an "an effort to show that there are two Saint Patricks and no God" adding to this, that "propagation of heresy and unbelief has nothing to do with polite learning" (Blather.net, 2004).

Brian O’Nuallain, anglicized as Brian O'Nolan, an author who goes by several pen names out of which Flann O'Brian is best known, had once attended a Catholic secondary school, Blackrock College. The allusions to Christianity can be observed throughout the whole novel, although they are contradictory and can vaguely suggest a support unveiling his own views on the subject. On the one hand the uncle is portrayed as a man of God with Pharisaic and Fanatic behaviors, evidencing the imperfectness of the Christian followers. "God's name" (O'Brien, p. 11) comes up quite often and it is generally overused by characters portrayed as villainous. The uncle, described as being "ratbrained, cunning, concerned-that-he-should-be-wellthought-of" (O'Brien, p. 30), in almost every appearance and dialogue uses expressions like: "God look down on us and pity us"(12), "Well faith"(10), "What in God's name" (11), "Lord save us" (1).

Another confusing, we might say, contradictory aspect regarding the Christian representation is Pooka's theory regarding "truth". Could this 'truth' be referring to an identitarian feature of Ireland? Could he be referring to the symbol of Christianity in a post-war modernist society? To the Holy Trinity? An interpretation could be that by bringing forth the mythological devil, the Pooka, as being a civilized, social, rat, a villain who insists upon the apparently nonsensical theory of "truth" being an "odd number", the author deplores the spirituality of a once Christian nation. The "odd number" can suggest the number three represented by the Irish clover leaf, a pagan symbol converted to Christianity (The Holy Trinity).

Moreover, the legendary hero of Irish mythology, Finn MacCool, portrayed as a villainous character, one who enjoys the sound of "wing-beating in the dark belfries, cowcries in pregnancy [...] lamenting of a wounded otter in a black hole" (O'Brien, p. 14) refers to himself as being a "hero from the crack of time": "I am Cuchulainn I am Patrick" (O'Brien, p. 19), making reference to a Christian identity, alongside the legendary names of Irish historical representatives Cuchulainn, Connachtman, Ulsterman, Goll etc. "Evil is even, truth is an odd number" is the first sentence of the ultimate conclusion. The "poor German" salutes the reader, concluding the novel with three goodbyes, as though they were the three endings for the three introductions, as though he had been writing the novel all along, obsessing with the number three, under one of his numerous masks.

It is interesting to observe that he associates this last character with the obsession with the number three, an odd number, the odd number mentioned by Pooka, the number of the three levels of fiction in the introduction, a number which had symbolized omniscience throughout O'Brien's education and upbringing in the spirit of Catholic ideology (The Holy Trinity). The number three was a sacred number for the druids and the Celtic religion and it is a sacred symbol to Christianity. As we can notice, the title of the novel, "Swim-Two-Birds", refers to a place of 
reconciliation in Irish Mythology, where pagan and Christian worlds meet" (Gallagher, p. 20).

We can conclude that O'Brian does not positively assess the Catholic environment (see representation of the uncle, part of the clergy) but it seems as though he enforces its essence, the ultimate representation of Christianity, being the Father, the Son and the Holy Spirit. Truth being an odd number, can refer also to the first encounter between man and Divinity when God showed Himself to Abraham in the form of Three Men (Gen.18:2) (Anania, p. 38), in the era before Christ, in the era of pagan divinities. The first representation of a Christian God in a pagan society was portrayed as three entities, an odd number. Could O'Brien have been deploring the Irish conflict between the two main religions of Ireland? Alluding to a reconciliation between the Protestant and Catholic? By insisting that truth is an odd number, was he insisting on the fact that there is but one truth and that it is formed of an odd number, insinuating the number three?

The puzzling plots entwine with reproductions of Irish myths, narrating a labyrinth of allusions and mockery. The levels of fiction are presented in the beginning of the novel in O'Brien's avant la letter postmodernist style introducing the "examples of three separate openings" (O'Brien, p. 9) and proving the unreliability of the narrator which features the ironized characters and situations. If we are to agree to the concept that O'Brien encoded his own personality and views through the mask of the undergraduate student, who himself is a writer describing Trellis as an author, which again resembles himself, we can extrapolate that through the statement: "One beginning and one ending for a book was a thing I did not agree with." (O'Brien, p. 9), O'Brian parades his response to the previous dogmatic era certifying his autonomous literary representation. The biographical reminiscences of the undergraduate student display the first level of fiction and continuously interrupt the embedded stories, as if the director of a movie continuously intervenes while the film is being played, justifying the reasons behind the plot, throughout the whole live session (e.g. "it was undemocratic to compel characters to be uniformly good or bad" (O'Brien, p. 25)).

The history of Ireland is sustained by two great pillars, reality and mythology. On the one hand, we can learn about the Irish High Kings, the musicians, bards, writers and warriors, on the other we can be mesmerized by giants, fairy kings and queens, leprechauns and talking animals. The legends surviving until today are sustained by the culture of the Celtic and Gaelic ancestral nucleus. The
Irish folk traces its roots back to the Iron Age, when a significant branch of the Indo-European people, speaking Celtic languages invaded the western island of Europe and settled there. They were known as the Celts.

The Celtic tribal groups found the soil of Ireland rich and fit for their cattle and farming. The Gaels, part of the Celtic folk dominated and guarded the island up to approximately 1170 A.D., when an Irish ruler would invite the Normans and English Crown into Irish disputes. Various archeological discoveries lead to the conclusion that the Gaels preserved the Celtic sacred traditions and beliefs, especially due to the fact that Ireland was not subject to the vastly extended Roman Empire. In a seemingly barbaric Celtic community, archeologists found traces of a god-like figure, Ogmios, holding an arch and bearing along the people, whose ears were tied to a golden thread connected to his tongue, proving the importance they gave to eloquence. According to the Celtic myth, the warrior, Finn Mac Cool, son of Cumail, also considers poetry and words as being magical weapons (Pons, p. 44). O'Brien's Finn Mac Cool gives importance to "sweet poetry and melodious Irish" (O'Brien, p. 17) but has a series of nonsensical and ludicrous solicitations for the "people of Finn" (O'Brien, p. 17) resulting in, what Derrida might call, the dissemination of the mythological spirituality. Another example of the decayed representation of myth would be the apparently elaborate "refinement of Finn Mac Cool" through speech, "clashing with Shannan's pedestrian English" (Gallagher, n.d.).

The archaism of the Celtic culture and belief, surviving in the Gaelic culture, is endorsed by the traditions and ideas originated in ancient India, as can be observed through a parallelism between Irish and Hindu laws (Eliade, p.120). The Christian religion brought by St. Patrick, flourished in the Gaelic olden days, due to certain resemblances with the pagan symbols ( e.g.: the trinities of aboriginal ancestral gods: Teutates, Esus, Taranis, or the female 'Matres' converted to the Three Marys (Vasilescu, p.331)). The Irish patron, Saint Patrick also converted certain Celtic symbols to Christianity, for example: The cloverleaf or shamrock, was once sacred to druids because it formed a triad, the number three being mystical in the Celtic religion, but Saint Patrick used it to demonstrate the Holy Trinity of Christianity. Although most of the laws, history, legends and traditions were preserved by verse, transmitted by word of mouth through the agency of druids, written literature and teaching were undertaken by the Christian monasteries, establishing thus, a connection between religion and the beginning of Irish civilization. The 
ancestral tribes, the Gaels, knew both the greek and latin alphabet and according to archeologists, the writings were mainly used in religious practices, to invoke divinities (Filarmo G., trans .Scriitoru, Dumitru, p.584). Again, we can extrapolate the link between religion and intellect, or in O'Nolan's words, "propagation of heresy and unbelief has nothing to do with polite learning".

By observing the mythological history of Ireland which includes the fairy kings and queens, the Pookas and the giants the heroes and the Saints, we can recognize a numerous number of fairytale as well as legendary personalities in At-Swim-Two-Birds. The Irish mythology occupies an entire corpus of literature, therefore O'Brien, employed, as he would say, some of the most popular names, to play a part in his novel. The mystical and mythical characters play the role of modern citizens and evidence a burlesque attitude. The mythological characters are a democratic bunch, acting out roles, in contradiction with their original characterizations. The Good Fairy is an aggressive, quarreling, poker-player, the bad devil, Pooka is a polite peace-maker, the legendary hero is a boastful dumb narrator and Sweeny plays the part of a judge in Orlick's level of fiction.

The undergraduate student introduces Finn Mac Cool as being a narrator of the story of Sweeny (an almost faithful reproduction of the myth: The Frenzy of Suibhne), a character in Trellis's manuscript and a character of the first level of fiction, of the undergraduate student's manuscript. Historically, he is believed to have been a warrior bodyguard for Cormac mac Airt, a High King of Ireland ruling Tara, but according to Celtic mythology, he is a hero belonging to the Irish mythological Fenian cycle, a giant and a semi-god. Although he uses archaic dialogue, even poetic verses, when speaking to his followers, some of which are considered his enemies in the original myths (Diarmuid Donn), he mocks the legends from the other cycles, displaying discontent even in regard to his own. $\mathrm{He}$ displays the clash between myth and trivia through his satirical remarks regarding the Tragedy of the children of Lir, a significant part of the first Mythological cycle:

"Who could think to turn the children of a king into white swans with the loss of their own bodies, to be swimming the two seas of Erin in snow and ice-cold rain without bards or chess-boards, without their own tongues for discoursing melodious Irish, changing the fat white legs of a maiden into plumes and troubling her body with shameful eggs?" (O'Brien, p. 21)

As well as regarding The Frenzy of Suibhne, part of the Historical cycle:
"Who could put a terrible madness on the head of Sweeney for the slaughter of a single Lent-gaunt cleric, to make him live in tree-tops and roost in the middle of a yew, not a wattle to the shielding of his mad head in the middle of the wet winter, perished to the marrow without company of women or strains of harp-pluck, with no feeding but stagfood and the green branches? Who but a story-teller?" (O'Brien, p. 21)

The severe mocking of the legendary myths, blaming the story-teller, implies a distrust in the messenger of the origins, of the story-teller, the one who, we might say, is responsible for the communication and passing on of truth. According to Roland Barthes, the myth itself is a language act, a message, continuing endlessly (Barthes, p. 235), therefore the messenger can be the myth itself. Thus, Finn Mac Cool, a legendary hero, a significant character in the mythological representations considers myth an unreliable system, mocking its structures. This deviation from propriety, the revolted citizen against its normative system, is a constant theme found between the lines of most fiction levels of At-Swim-Two-Birds. The undergraduate is reluctant to the norms of his uncle, his 'landlord', the characters mutiny against their creator Trellis, and the great mythological hero distrusts the veridical character of the myth. Could this be the allusion of one man's distrust in the contemporary social system? Could it be a revolt against the truth praised by the contemporary society? O'Brien mocks the legendary hero, Finn by presenting him as an almighty, villainous, dim-witted, hulk-of-a-man:

"Who has heard honey-talk from Finn before strangers, Finn that is wind-quick, Finn that is a better man than God? Or who has seen the like of Finn or seen the living semblance of him standing in the world, Finn that could best God at ball-throw or wrestling or pig-trailing or at the honeyed discourse of sweet Irish with jewels and gold for bards, or at the listening of distant harpers in a black hole at evening? Or where is the living human man who could beat Finn at the making of generous cheese, at the spearing of ganders, at the magic of thumb-suck, at the shaving of hoghair, or at the unleashing of long hounds from a golden thong in the full chase, sweet-fingered corn-yellow Finn" (O'Brien , 2001, p. 19)

The mythical names that O'Brian displays, surfacing at the beginning of the novel, (e.g. 'Diarmuid Donn', 'Caolcrodha Mac Morna', 'Diarmud O'Diveney of Ui bhFailghe') represent a clear infuse of Gaelic ancestry. We can observe that he did not use the Anglicized version when naming the followers of the hero, Finn MacCool. The ironized version of loyal authentic followers to a king can be extrapolated, in 
this case, to a hero with an Anglicized name, indicating an allegiance to a foreign origin. A ridiculed representation of Irish history can be brought into discussion, recalling the King of Lenister, Diarmait Mac Murchada who pledged allegiance to Henry II of England in order to regain his sovereignty from a High King of Ireland. Thus, a 'hero' of Ireland, later known as the 'Diarmait of the Foreigners' with, most probably, Irish subjects, opened the gateway to what would become later, the English invasion.

The author introduces the ancestral names into a trivial storyline, minimizing their heroic character. The ridiculed association of great ancestral Irish names, applauding a boastful hero, a hybrid Finn MacCool, is evidenced by the hero's capacities of "making great cheese", or "the magic of thumb-suck". Moreover, O'Brian's "legendary hero of Ireland" is "fond of wingbeating in the dark belfries, cow-cries in pregnancy, lamenting of a wounded otter in a black hole", sounds that Finn MacCool considers "sweeter than harpstrings (sic)". Is this a reference of revolt against the contemporary leaders?

The very nature of a hero is to inspire, to be admired for positive deeds fulfilled for the benefit and wellbeing of those around him. Starting from the "kingdom of creation", of his own mind (O'Brien , p. 13), the author of the "Third opening" encounters the mocked hero of Ireland coming out "from his shadow" (O'Brien , p. 13), predicting the unnatural character he possesses. O'Brien implies that each society, each generation, indifferent of location or time commits to certain ideals of man, to exemplars. In the society created by the young undergraduate, implicitly by O'Brien, the champion has the traits of a birdbrain villain. Not only does the Irish legendary hero of the novel's "Third opening" lack altruistic essence, but his own poetic hymn makes reference to his exaggerated boastfulness "I am Patrick", "I am Goll", "I am my own father and my son". The "God-big Finn", a "pleasing eulogy" demonstrates the mockery of the Irish heroic era, of the romantic, spiritual era, thus, satirized and deplored. A, once, Christian Ireland, fighting the protestant English, for decades defending its language, traditions and Christian beliefs, encodes O'Brian, in contemporaneity remains desolated and stripped of essence by 'heroic' leaders, as Finn MacCool. James Joyce's influence can be suggested, as he too, considered heroism as being only a deception, "the whole structure of heroism is, and always was, a damned lie"( Joyce, introd. Declan Kiberd, p.10).

O'Brien introduces the ironized legend of "Buile Suibhne" also known as "The frenzy of Sweeny" (O'Keeffe, 2013) through a dialogue between the great Irish hero Finn
Mac Cool and Conan, another mythological character, also known as the son of Finn (Monaghan, p. 75).The mythical characters discuss a mythical legend, as if they are talking about their neighbor, interrupting the narration with mundane comparisons. The legend narrated by Finn suggests that Sweeny, instead of being annoyed by St. Ronan because of marking a site for a church, as O'Keffe's translated version of the myth narrates, is annoyed by the "saint-bell of saints with sainty-saints" (O'Brien, p. 65), mocking an element from another Irish legend, where Saint Patrick supposedly used his bell to rid Ireland of serpents.

O'Brien's story of Sweeny seems to mock the myth of The Frenzy of Sweeny, satirizing also the value of Irish myths. We can observe the paternal characters in a cartoon like, comical story line, where an Irish king runs around naked throwing out the psalter of cleric, the representative of the Catholic church and the King, a representative of sovereignty, seem as if they are but mere ridiculous puppets. We could extrapolate from this, the mocking, the adversity and puppetry of the two main institutions of society, of the two leading pillars, the church and government. The rivalry of Ronan and Sweeny can allude to the deplored controversy regarding which institution rules Ireland, the Catholic church or the parliament? Furthermore, both characters demonstrate deviations, contradictory behaviors: The saint, instead of giving out blessings, gives out curses "My curse on Sweeny!"; whilst the very essence of Christian behavior is to pray for and love all, even those who cause you harm, without resorting to any kind of revenge. The king, instead of manifesting credibility, stability and honor, traits necessary for leaders, violates "the guarantee by the slaughter of a man every morning before the hour when fighting was permitted" (O'Brien , p. 65) and generally goes mad due to uncontrolled anger. Thus, they are both presented, in myth and in contemporary representation, as unfit leaders.

Being born in a Gaelic family who was interested in the revival of Gaelic traditions and language, Brian O'Nolan's work, even though satirical, is studded with glorious romanticism, where good prevails over evil. As we can observe in At-Swim-Two-Birds, reconciliation between adversities prevails, the undergraduate accepts the gift from the uncle and Trellis is saved. The character-author's intention to create a villainous destiny for his characters is mutinied by the characters themselves. These fictional puppets, borrowed or stolen from other fictions, do not agree with the author's pessimistic vision regarding their future roles in the storyline. 
A parallel can be made with another modernist literary masterpiece. George Orwell's characters in the novel Nineteen-eighty-four (first published ten years after At-Swim-Two-Birds) in which the lead characters realize their puppet-like complexion, plot against the system, against Big Brother and exercise an existentialist attitude, even in the face of torture. The characters of O'Brien's novel "fell in love and the villain Furriskey, purified by the love of a noble woman, hatched a plot for putting sleepingdraughts in Trellis's porter [...] took a house in Dolphin's Barn and opened a sweety-shop and lived there happily for about twenty hours out of twenty-four" (O'Brien, p. 100). Dermont Trellis, one of the character-authors plays the role of an almighty god, his power lying in his words, in is writing, as the characters state: "He'd talk the lot of us into the one grave if you gave him his head".

Thus, we can extrapolate, not only another invocation of Ogmios by stating the importance of eloquence, but also the pulse of the working class in O'Brien's vision. A group of ordinary people, far from having hero-like dispositions, become conscious of their role-play and the strings which are being pulled. They become aware of their inferiority and vulnerability, but do not remain passive to the actions of "Mr Storybook" and act out on their own.

Underlining "if you gave him his head" with emphasis on the importance of 'the head' which makes the object of power, I would like to suggest another codification linked to the Irish mythology and ancestral traditions. Within the Celtic wisdom, the ancestral forerunners of Gaels, the 'head' was the temple of the spirit, the receptor of sacred force, of divine origin, powerful and protective, being considered valuable even after death (Eliade, 2011). This idea, the valuing of the head, surfaces throughout O'Brien's novel, although taking different forms of representation, as: "retired into the kingdom of my mind" (O'Brien , p. 13), and "treasury of my mind" (O'Brien , p. 21), "privacy of my mind" (O'Brien , p. 9) directing our thoughts towards the ancestral Celtic beliefs. Although the elements, characters and symbols make use of the ancestral Irish culture parodied with contemporary behavior, the language O'Brien uses, seems generally to display a nonsensical mix of English and Irish. According to Brian Rock the use of mixed language aims to "deterritorialize (sic) the significations in both languages in his production of a hybrid linguistic form". (Rock, p. 134) The overall pamphlet-like tonality can suggest the hybridized essence. "The penetration of myth into the modern world" (Gallagher, p. 8) is sustained by the linguistic factor, the hybridity of language, defines Loyd, is "a process of cultural mixing and juxtaposition in which the traditional is combined and inflected with the modern or the native with the Western" (Rock, p. 135).

The reality show culture is exhibited transparently in the novel through the "synopsis", defined as a "summary of what has gone before, FOR THE BENEFIT OF NEW READERS", mentioned and being referred to more than once. Such clarifying staccato evidences the novel's interrupted train of thought. The ironic interruptions resemble the future TV reality shows, constantly interrupted by advertisements, using a short summary to reintegrate the watcher's mindset into the story-line's plot. Although they mean to summarize and clarify the plot, O'Brian introduces new information, not mentioned within the previous pages, confusing the reader, luring the imagination into unknown territory.

At Swim-Two-Birds has no clear chronological line, the characters relate their own stories, constantly interrupted by other characters hired by Mr. Storybook. One of the circus-like representations includes Sweeny the King, the mad-man living in the trees, being deplored by his subjects "Sad it is Sweeny [...] that your last extremity should be thus, without food or drink or raiment like a fowl, the same man that had cloth of silk and of satin and the foreign steed of the peerless bridle [...] Sad it is to see the same man as a helpless air-fowl" (O'Brien , p. 69). The deplored, glorious and courageous Irish spirit could be suggested here. An Ireland which, throughout history, was not complacent under foreign domination, rising in revolt against its suppressors, is stripped of its forcefulness.

Even though the novel is widely recognized as representing the postmodernist avant-garde through metanarrative, irony and metaphysics, it seems to also include traits of realism and modernism. It is true that the narrators within the storyline are aware of a reality which is uncertain, unknowable and ever-shifting.

Nevertheless the characters appear in the story through accumulation of environmental details comparable to Honore de Balzac's Comedie Humaine. Modernist traits can be identified in the character's disorganized talking and a clear acknowledgement of the irrational world politics (see trial of Trellis regarding the birth of Furriskey). Decay and fragmentation are suggested also through the mockery of contemporary society. The disjointed structure, an obvious modernist trait, reflects the dysfunction of the Western society. Instead of progress and growth, modernist intelligentsia portrays the decay and absurdity of a 'developed' society. Post-modernism relativism is also a 
part of At Swim-Two-Birds where 'truths' are conceived of social constructions depending on race, power, class and gender.

The "colloquy" between the Good Fairy and Fergus MacPhellimey is another example of mythical characters expressing a mundane attitude discussing spiritual matters. The encounter of a Good Fairy, "brighter than the first shaft of day" (O'Brien, p. 104) and "a devil or pooka" (O'Brien, p. 107) suggests a certain degree of relativity regarding good and evil. The devil is a humble, gentleman-like creature, entertaining the Good Fairy with an allusive discourse, eating the loins of human and dog (O'Brien, p. 105), but with an inclination to attenuate conflict. On the other hand, the Good Fairy is one that smokes cigarettes and threatens Shorty "to kick the jaw off" (O'Brien, p. 116) his face, displaying an aggressive attitude towards his companions. The mix of mythical allusions and banal incidents fuels the discussion between the representative of good that seems evil and the evil that seems good. The debate between the number of tails the pooka has, or whether kangaroos are human or not, intertwined with a possible outcome of a fairy/devil offspring, the nonsensical statements being tangled with existential philosophical ideas, the mention of the fairy's "own existence" which "was provoked by the vitality" (O'Brien , p. 109) of the devil's evil are disruptive of the order of coherent meaning.

The dialogue between the Good Fairy and Pooka, the devil, is almost as if the characters were answering with absurdity to absurdity. The author brings the two fairytale creatures into the post-war reality when Pooka mentions how much his coat cost before the war and the Good Fairy mentions the strikes "of the workin' man" which are the cause of the "price of bread" and bacon. Absurd enough that a bodiless fairy creature should mind the prices of food. The technological revolution proceeding World War I is deplored by O'Brien through the devil and his coat, "a coat in the old days was made to stand up to rough wear and was built to last". His opinion regarding the contemporary problems surface through the devil's logic, "there is no subterfuge of economy more misconceived than the purchase of cheap factory-machined clothing".

The characters and surroundings, the devil, the fairy, the wife of the devil, the poet and two men, could resemble Lewis Carrol's world from Alice's Adventures in Wonderland. As well as Alice, who finds the talking flowers and disappearing cat odd, the two men, Shorty Andrews and Slag find it hard to believe that a bodiless fairy could be talking to them from the pocket of a devil.
Moreover Furrinskey talking to the cloud can resemble Alice talking to a disappearing cat, the many doors O'Brian's character opens can also resemble the many worlds Alice enters into. The poet, Jem Casey, on the other hand, referring to the strange world they are in, could believe anything "even a maggot talking", suggesting man's acceptance of being ridiculous.

The poems included in the text, "honey-words" recited by the characters in different situations, can be another allusion to Celtic mythology. According to De Bello Gallico VI 14, the cultural patrimony was transmitted to descendants orally in poetic guise. (Filoramo, et al., p. 80) Memory was an important value in their culture, a reason for which the druids were respected and looked up to by the Celtic community. The melodious verse and "honeywords" mentioned repeatedly in O'Brien's fractured masterpiece, although parodied, could suggest the ancient values of Ireland.

The Celts and Gaels believed they were a sacred people, descending from gods and they would return to them in their afterlife, as extrapolated from the findings linked to their religious practices (Reșceanu \& Boldisor, pp. 178-189). According to Cesar, resulting from their behavior, during their lives, the Celts were in permanent connection with divinity. O'Brien's characters, mythological or not, religious or not, also appear to be in a permanent connection with Divinity. The uncle's expressions include "What in God's name?" (O'Brien , p. 11) and God look down on us" (O'Brien , p. 12), and other God related expressions in numerous occasions. Diarmuid Don and Conin, the followers of Fin, also include the name of God in their speeches ("for the love of God" (O'Brien , p. 18)) several times. Even Kelly, the undergraduate's friend, includes God's name in his dialogue "by God" (O'Brien, p. 24)). Slug and Shorty, Pooka and the Good Fairy employ similar expressions and the list could go on.

In conclusion, the obvious mix of mythical allusions and banal incidents, combined in a fractured storyline, doubled by O'Brien's codification and contradictory references, set the stage for a postmodernism literary scene. It can equally represent the protest against contemporary society and of Irish origins. Although many of the stories and representations display a bizzare cul de sac, the last conclusion seems to end on clearance note. The intellectual, displaying out of the ordinary behaviors, like not sitting in fear of his "glass bottom", argues the last narrator, is still an intellectual and can "ramble throughout the labyrinths of mathematics", referring to his valid intellectual abilities. Therefore, irrespective of one's beliefs 
or possible frenzies, his value should not be ignored and turned down, on account of his oddity. Although one is odd he could still carry truth, one might conclude. Truth can truly be an odd number under so many masks.

\section{REFERENCES}

Barthes, R., 1997. Mitologii. Colectia Sinteze 15 ed. Iasi: Institutul European.

Berciu, M., 1970. Lumea Celților. București : Editura Ştiințifică.

Blather.net, 2004. Blather. [Online] Available at: http://www.blather.net/theblather/2004/01/flann_obrien_an d_erwin_schrdin/

[Accessed 28 March 2017].

Eliade, M., 2011. Istoria Credințelor și a ideilor religioase. Iași: Polirom.

Gallagher, M., n.d. Dalkey Archive Press. [Online] Available at: http://www.dalkeyarchive.com/product/atswim-two-birds-by-flann-obrien/

[Accessed 0607 2017].

Joyce, J., 1992. Ulysses. with an introdiction by Declan Kiberd ed. London : Penguin books.

Monaghan, P., 2004. The encyclopedia of celtic mythology and folklore. United states of America: Facts on File, Inc.

O'Brien , F., 2001. At-Swim-Two-Birds. London: Penguin Group.

O'Keeffe, J., 2013. Internet Archive- The Frenzy of Suibhne. [Online]

Available at: https://archive.org/stream/builesuibhnethef12okee/builesuib hnethef12okee_djvu.txt

[Accessed 0407 2017].

Pons, M. M., 2003. Mituri fundamentale: Mitologia Celtica. Bucuresti: Meteor Press.

Reșceanu, S. \& Boldisor, A., 2009. Istoria Religiilor, Religiile antice, Curs-partea I, Vraiova: Editura Universitaria Craiova.

Rock, B., 2010. Irish nationalism and postcolonial modernity: the 'minor' literature and authorial selves of Brian O'Nolan, s.1.: University of Sterling.

Vasilescu, E., 1982. Istoria Religiilor. Tipărită cu binecuvântarea Prea Fericitului părinte IUSTIN, Patriarhul Bisericii Ortodoxe Române ed. București : Editura Institutului Biblic și de Misiune al Bisericii Ortodoxe Române .

Walsh, D., 2004. Blather.net. [Online] Available at: http://www.blather.net/theblather/2004/01/flann_obrien_an 